\title{
P01-015 - Effect of Cochicine on cholesterol in FMF and BS
}

\author{
S Ugurlu', E Seyahi ${ }^{1 *}$, I Hanci ${ }^{1}$, SM Pehlevan², H Ozdogan ${ }^{1}$, H Yazici $^{1}$ \\ From 7th Congress of International Society of Systemic Auto-Inflammatory Diseases (ISSAID) \\ Lausanne, Switerland. 22-26 May 2013
}

\section{Introduction}

We and others have previously shown that patients with Familial Mediterranean Fever (FMF) had low cholesterol levels when compared to healthy controls $[1,2]$. This was initially brought up by Ozkan E [3]. The causes of this abnormality are not understood. It could be due to an inherent effect of FMF or due to a lipid lowering effect of colchicine, as the patients in these studies were all regular users. Additionally, earlier studies had suggested that colchicine may have hypocholesterolemic effect.

\section{Objectives}

We conducted a 12 week study to determine whether colchicine would decrease serum lipid levels in patients with FMF and Behçet's syndrome (BS). Lipid levels were measured in each patient before and after colchicine use.

\section{Methods}

Blood cholesterol and triglycerides levels were measured in 24 patients with FMF $(11 \mathrm{M}, 13 \mathrm{~F})$ and $16(8 \mathrm{M}, 8 \mathrm{~F})$ patients with BS who were registered at the outpatient clinic of Cerrahpasa Medical Faculty. All patients were naive to colchicine or immunosuppressive treatment or any other lipid lowering drugs at study entry. Blood cholesterol and triglycerides levels were measured again after 12 weeks of colchicine $1.5 \mathrm{mg}$ daily. Colchicine was withdrawn in one patient with FMF because of liver toxicity and in another because of nausea. Two patients with FMF did not use colchicine and another with FMF was lost to follow-up. Colchicine was switched to azathioprine in 1 patient with BS because of active disease.
Only patients who completed 12 weeks period were analyzed.

\section{Results}

There were 19 ( $8 \mathrm{M}, 11 \mathrm{~F})$ patients with FMF and 15 (7 M, 8 F) patients with BS who completed the 12 week period. Patients with FMF were (mean age: $33.8 \pm 14.1$ years) significantly younger than BS patients (mean age: $36.5 \pm 9.5)(P=0.001)$. Colchicine did not change cholesterol and triglycerides levels in patients with FMF (T.Cholesterol: $169 \pm 77$ vs $181 \pm 48 \mathrm{mg} / \mathrm{dl}, \mathrm{P}=0.58$, Triglycerides: $122 \pm 82 \mathrm{vs} 128 \pm 70 \mathrm{mg} / \mathrm{dl}, \mathrm{P}=0.75$, LDL: 120 \pm 44 vs $112 \pm 40, \mathrm{P}=0.35$, HDL: $42 \pm 13$ vs $47 \pm 11 \mathrm{mg} / \mathrm{dl}$, $\mathrm{P}=0.1$, before and after colchicine use, respectively). This was also true for BS patients (T.cholesterol:181 \pm 51 vs $172 \pm 44 \mathrm{mg} / \mathrm{dl}, \mathrm{P}=0.53$, triglycerides: $112 \pm 63$ vs $107 \pm 52$ $\mathrm{mg} / \mathrm{dl}, \mathrm{P}=0.18$, LDL: $115 \pm 38$ vs $106 \pm 40 \mathrm{mg} / \mathrm{dl}, \mathrm{P}=0.85$, HDL: $48 \pm 9$ vs $48.3 \pm 9.9 \mathrm{mg} / \mathrm{dl}, \mathrm{P}=0.3$ ).

\section{Conclusion}

This study provided no evidence that colchicine use affects lipid levels in patients with FMF and BS.

\section{Disclosure of interest}

None declared.

\section{Authors' details}

${ }^{1}$ Department of Internal Medicine, Division of Rheumatology, Cerrahpasa Medical Faculty, University of Istanbul, Turkey. ${ }^{2}$ Department of Internal Medicine, Division of Rheumatology, University of Fatih, Istanbul, Turkey.

Published: 8 November 2013 


\section{References}

1. Ugurlu S, Seyahi E, Cetinkaya F, Ozbakir F, Balci H, Ozdogan H: Intima-

media thickening in patients with familial Mediterranean fever.

Rheumatology (Oxford) 2009, 48(8):911-5.

2. Akdogan A, Calguneri M, Yavuz B, et al: Are familial Mediterranean fever (FMF) patients at increased risk for atherosclerosis? Impaired endothelial function and increased intima media thickness are found in FMF. J Am Coll Cardiol 2006, 48:2351-3.

3. Ozkan E, Okur O, Ekmekci A, Ozcan R, Tag T: A new approach to the treatment of periodic fever. Med Bull Istanbul 1972, 5:44-9.

doi:10.1186/1546-0096-11-S1-A19

Cite this article as: Ugurlu et al:: P01-015 - Effect of Cochicine on cholesterol in FMF and BS. Pediatric Rheumatology 2013 11(Suppl 1):A19.

Submit your next manuscript to BioMed Central and take full advantage of:

- Convenient online submission

- Thorough peer review

- No space constraints or color figure charges

- Immediate publication on acceptance

- Inclusion in PubMed, CAS, Scopus and Google Scholar

- Research which is freely available for redistribution

Submit your manuscript at www.biomedcentral.com/submit
C Biomed Central 